\title{
DYSFUNCTIONAL FAMILIES AND CRIME: RIGHTING WRONGS
}

\author{
Zaleha Kamaruddin*
}

\begin{abstract}
The number of youths involved in crime and who show disregard for law and order is on the rise. What is more disturbing is the rise of violent crimes committed by them. The author argues that these concerns need to be addressed seriously. Pertinent questions need to be answered to understand the underlying reasons. This article is divided into three parts: the first part defines dysfunctional families and their relationship with crime and some home-truths relating to them. The second emphasises the importance of knowledge and the inculcation of good values to individuals through the family. In the final part some recommendations are made.
\end{abstract}

\section{Introduction}

Tan Sri Lee Lam Thye the Vice-Chairman of the Malaysian Crime Prevention Foundation and Malaysia's Inspector General of Police, Tan Sri Ismail Omar both raised their concern about the recent increases of crime among youths. ${ }^{1}$

Many community leaders from all over the world have raised their worry and concern as well. These concerns need to be addressed seriously. Pertinent questions need to be answered to understand reasons behind the phenomenon. Why are our youths behaving this way? Why are they putting their future in jeopardy? How can we make these wrongs right?

This article attempts to shed some light on these questions. It attempts to synthesise whatever limited knowledge that exists on this subject. It does not claim to present a complete and comprehensive understanding of the various types of dysfunctional families which exist in certain contexts in different cultures and countries. Rather, it focuses on the importance of inculcating values which is the missing factor in dysfunctional families. It is also important to note that the basis for this factor is that values are very important and are considered as one of the most effective means to regulate society. This is because the approach used is more of changing

* Zaleha Kamaruddin is the Deputy Director-General of the Malaysian Institute of Islamic Understanding (IKIM), Kuala Lumpur. 
from within, i.e. 'inside-out', compared to for example using law which is more of an 'outside-in' approach. It is well-documented ${ }^{2}$ that the arms of the law are far too short to solve all crimes and this failure will be more prominent without proper and adequate enforcement.

\section{Dysfunctional Families and Crime: Some 'Home-Truths'}

A review of empirical evidence in the professional literature of the social sciences leads us to a common factor in answering the above questions; i.e. the family.

The first home-truth: the rise in crime and violent crime parallels the rise in dysfunctional families. ${ }^{3}$ Families are considered dysfunctional when conflict, misbehaviour, and often abuse on the part of individual members occur continually and regularly, and are leading other family members to accommodate such actions. Children sometimes grow up in such families with the understanding that such an arrangement is normal. Dysfunctional families are primarily a result of co-dependent adults, and may also be affected by addictions, such as substance abuse (alcohol, drugs, etc.). Others also include untreated mental illness and parents emulating or over-correcting their own dysfunctional parents.

A common misperception of dysfunctional families is the mistaken belief that the parents are on the verge of separation and divorce. While this is true in a few cases, often the marriage bond is very strong as the parents' faults actually complement each other. In short, they have nowhere else to go. However, this does not necessarily mean the family's situation is stable. Any major stressor, such as relocation, unemployment, illness, natural disaster, inflation, etc. can cause existing conflicts affecting the children to become much worse. ${ }^{4}$

The second home-truth: crime and youth criminal behaviour has its roots in habitual deprivation of parental love and affection going back to early infancy. Similarly, sexual abuse in childhood often leads these victims to become sexual predators as adults. ${ }^{5}$ Delinquents have a chaotic, disintegrating family life. This frequently leads to aggression and hostility toward others outside the family. Many inmates on death row have histories of some kind of severe abuse. The neglect and abuse of children often progresses through several generations. The cycle of abuse and crime keeps repeating itself. The cycle of violence concept, based on the quality of early life relationships, has its positive counterpart. Supportive and loving parents who respond to the basic needs of their child instil self-confidence and an interest in social environments. These children are generally well-adjusted in relating to others and are far less likely to commit crime.

By the late twentieth century, the general public had not accepted that criminal behaviour is a psychological disorder but rather a wilful action. The public cry for more prisons and tougher sentences outweighed rehabilitation and the treatment 
of criminals. Researchers in the twenty-first century, however, continued to look at psychological stress as a driving force behind some crimes. Only in recent decades has the dysfunctional family been taken seriously by professionals (therapists, social workers, teachers, counsellors, clergy, etc.), especially among the middle and upper classes. Any intervention before that would have been seen as violating the sanctity of marriage and increasing the probability of divorce. Children were expected to obey their parents (ultimately the father), and cope with the situation alone. ${ }^{6}$

Third home-truth: most delinquents are children who have been abandoned by their fathers. They are often deprived of love and affection. Many fathers abandoned their families, when the responsibilities of life and parenting become too much for them. Reasons that caused these men to leave include: their own abandonment issues from childhood, problems with the children's mothers, addictions, an inability to handle parental responsibilities at the time, and not wanting a child.

Fourth home-truth: inconsistent parenting, family turmoil, and multiple other stressors compound the rejection of these children by parents. Findings from research conducted by Kevin Wright confirm that children raised in supportive, affectionate, and accepting homes are less likely to become deviant. ${ }^{7}$ Scholarly evidence suggests that at the heart of the sudden increase in crime is the loss of the capacity of fathers and mothers to be responsible in caring for the children they bring into the world. This loss of love and guidance at the intimate levels of marriage and family has broad social consequences for children and for the wider community. Empirical evidence also shows that too many young men and women from dysfunctional families tend to have a much weaker sense of connection with their community and are prone to exploit its members to satisfy their unmet needs or desires. This contributes to a loss of a sense of community and to the disintegration of societies into social chaos and violent crime. If policymakers are to deal seriously with the root causes of crime, they must first strengthen the family institution. ${ }^{8}$

Fifth home-truth: conforming to Merton's sociological theories, ${ }^{9}$ a survey of inmates in state prisons in the US (late 1990s) showed very low education levels. Many could not read or write above elementary school levels, if at all. The most common crimes committed by these inmates were robbery, burglary, automobile theft, drug trafficking, and shoplifting. Because of their poor educational backgrounds, their employment histories consisted of mostly low wage jobs with frequent periods of unemployment. Employment at minimum wage or below living wage does not help deter criminal activity. Even with government social services, such as public housing, food stamps, and medical care, the income of a minimum wage household still falls short of providing basic needs. People must make a choice between continued long-term low income and the prospect of profitable crime. Gaining further education, of course, is another option, but classes can be expensive 
and time consuming. While education can provide the chance to get a better job, it does not always overcome the effects of parental abuse, or other limiting factors.

\section{Strengthening the Family through Islamic Education}

Al-Ghazāli (d. 1111) in his Book of Knowledge wonders how one who sought no knowledge can be moved to any noble deed. One of his wise men also said that "Verily, I pity no one as I pity the man who seeks knowledge but understands not and him who understands and seeks it not." ${ }^{10}$ The root for this according to al-Ghazāli is that knowledge is one of the most fundamental features of Islam. In its various derivations, it is one of the most frequently occurring terms in the Qur'ān; besides Allah and Rabb (the Creator and Sustainer). The Prophet himself emphasised the significance of knowledge at every prospect and commended those who are learned and those who are in search of knowledge. On top of that the pursuit of knowledge was made a religious obligation for every believer. For the Muslims of the classical period, Islam was synonymous with knowledge; without such knowledge, an Islamic civilisation was inconceivable.

In his Preface to al-Ghazāli’’s Book of Knowledge, Ziauddin Sardar points out that

[i]n classical Muslim civilisation, advices from the scholars were not only eagerly sought after but also seriously acted upon. Indeed, the flourishing classical Muslim civilisation was totally obsessed with knowledge: with seeking it, acquiring it, talking and arguing about it, defining it, building institutions for dispensing it, writing about it, reading about it, collating it, and disseminating it. ${ }^{11}$

The main question in the context of this article is what kind of knowledge are we imparting to our children to ensure that Islamic civilisation persists? Indeed, with the rise in crime rate in our society, there is definitely something wrong with our present education system and our family institution. Social problems are one of the indicators of a sick society and something serious must be done. To improve quality, productivity and performance of Islamic education in the context of the family in the Muslim world, a plan of action must be put into place by including these factors; focusing on the individual in the family by illuminating knowledge and re-educating the Muslim intellectuals and educators, helping the vulnerable families and enhancing the role of religious leaders.

\section{Focus Group: The Intellectuals}

The roles of intellectuals in Muslim societies are important because reformist ideas must focus on the demands of the real world. Without a firm grasp of contemporary reality - in the context of this article, i.e. crime - Muslims will be marginalised in the modern world. 'Islamic knowledge' will be seen as outdated because the 
intellectuals could not make any interconnection and diversify which is a basic prerequisite for survival.

In his article "Reformist Ideas and the Muslim Intellectuals", Ziauddin Sardar calls for the emergence of a new breed of Muslim intellectuals who are

interested in abstract ideas as well as specifics, the real world demands both. Unlike Socrates, they are not interested in ideas for ideas' sake. They search for ideas that lead to reform, but like Socrates they seek propagation of thought, criticism and questioning attitude, a goal for which they would eagerly lay down their lives [...]. They do not have acquisitive and analytical minds only, but also critical, imaginative and creative minds. They engage and transform..$^{12}$

\section{Focus on the Individual in the Family}

With the current challenges to the family institution, how do we develop responsible individuals who can stand against the odds? Finding answers to this question is not easy. Although there are a range of approaches to this complex situation, a reliance on qur'ānic-based theory holds a number of advantages.

A logical basis would be developing the potential of that individual through his family. This would form the basis of the distribution of power and resources within the family which will shape those of the larger community. The family serves as one of society's primary sources of moral education. It is acknowledged that it is in the family that we first encounter issues involving power and justice. Because of the primacy of family life as the determinant of social structure, individual values are crucial to lessen if not eradicate crime.

This article finds strong support in ideas formulated by Ibn 'Āshūr in his treatise Maqāssid al-sharī'ah, where he states that this scenario is evidenced by not only the shari ' $a h$, but other different systems of law which emphasise the founding principle of the family unit, namely the association between woman and man through a valid marriage. This bond is the root from which stems human procreation and that spreads the notion of kinship (qarābah). The marriage gave rise to motherhood (umümah), fatherhood (ubuwwah), and filiations (bunuwwah), and later the relationship of brotherhood (ukhuwwah) and other more distant kinship ties. ${ }^{13}$

It is an acknowledged fact that the shar $\bar{l}^{\prime} a h$ has given marriage an important position and considers it as the fountainhead of all virtues. It is a basis of responsibilities and implementation of them. This is clearly indicated in the qur'ānic verse which emphasises the need for humans to marry: "And among His signs is this: He created for you from amongst yourselves, so that you might live in tranquillity with them, and put love and kindness in your hearts. All those are signs for people who reflect." 14 
It is also proposed that an individual's actions must be based on tawhīd. Tawhìd requires mankind to adhere to the concept of oneness of God and obey Him. The values of tawhìd will ensure that every individual follows the laws prescribed by Allah. The theory of vicegerency (khiläfah) affirmed that God's creation is deliberate and not accidental. Family, being the most important institution, should be the first to actualise man's vicegerency to Allah and it is therein that man has his first training in the real meaning of khiläfah. ${ }^{15}$

It is important for man to be educated and aware of his role as khaliffah. The Islamic education (informal and formal) should focus on man as khaliffah and the purpose of his creation because it would lead to a deepened consciousness on the responsibility of man in this world. In the context of this article, since family is the basis of society, it is pertinent to evaluate the roles and responsibilities of each member of the family from the familial aspect first.

Evaluation on the roles and responsibilities of man would eradicate crime in the society. One, because in the Islamic conception of man (which is based on the principle of al-insān kämil), man is considered perfect ( $k \bar{a} m i l)$ in the sense that he has been endowed with the necessary reason and understanding, intuition, and all the necessary prerequisites for him to perform his duty as khalif $f a h$. This is evidenced through Qur'ān 51:56 where Allah gives the purpose of His creation; i.e. He created the jinn and mankind that they might worship and pay devotions to Him alone.

In Qur'ān 2:31-4, Allah specifically mentions reasons for man to be appointed as khaliffah, i.e. only man has been given the necessary intelligence, strength and divine guidance.

The philosophical understanding of the nature of man and the purpose of creation is to be emphasised in our education to our children because without these, man will not be able to realise his role effectively. Ibrahim Zein has pointed out that as khaliffah, they are supposed to have acquired better judgement and self-control to understand Divine guidance. He highlighted the concept of trust (amānah) which determines the individual's relationship with the family, society, state, government, and humanity at large. Man is said to be attached to these institutions both materially and spiritually. ${ }^{16}$

He further elaborates that amānah establishes man's responsibility toward his kin, other human beings and socio-political institutions. This concept resolves the issues pertaining to the rights and responsibilities of individuals in every facet of his life starting with his family. The basis of man's humanity is responsibility (taklīf). He summed it up as "someone's right is someone's responsibility". ${ }^{17}$ In this context, Abdullah Yusuf Ali has rightly commented that the age of marriage is the age when they reach their maturity, regardless of whether that is before or after 18 years. ${ }^{18}$

Applying the same concept as stated by the Qur'ān on amānah as the cornerstone to the establishment of institutions to govern society, the family as the smallest unit 
of the society would be the first institution to practice it. This idea is founded on the fact that the fourth sūrah of the Qur'ān, al-Nis ${ }^{\prime}$, which deals with issues on good governance, describes the idea of absolute human equality in the context of the family. In the family the legally married man and wife are entrusted with the amānah of raising their children by providing maintenance, care, and education. The Qur'ān reminds us that when amānah are fulfilled, it will bring good to us.

The concept of amānah is important because it determines the individual's relationship with family, society, state, and humanity at large. It also establishes man's responsibility towards his kin, other human beings and socio-political institutions. In other words, this concept resolves the issues pertaining to the rights and responsibilities of the individual in every aspect of life.

The concept of khiläfah which is governance at an individual level encompasses the concept of trust (amānah), sincerity (ikhlās), truthfulness (sidq), competence and justness ('adālah) as the essence of qur'ānic guidance on good governance. The essence of amānah is the sense of accountability. In Qur'ān 8:27, Allah reminds us not to betray the truth of God and the Prophet, nor misappropriate knowingly things entrusted upon us.

In dealings with other people, justice should be implemented no matter what. The khalïfah needs to honour amänah and implement justice. Justice as one of the important principles of governance guides mankind as khalif $f a h$ in order to ascertain social justice. In Sürah Al-Nisā' verse 58, Allah has commanded man to deliver trusts to those whom they are due, and whenever they judge between people, they must judge with justice. In delivering these trusts, man is guided as indicated by verse 4:59, to follow God, follow the Prophet, and those from among man who have been entrusted with authority.

Another important component that has been highlighted by various scholars is shürā. The Qur'ān emphasises this in various issues on governance. It is a democratic decision-making process in solving problems and making decisions. At the same time, it actually restricts absolute power by leaders through the involvement of stakeholders which implies transparency, freedom of expression, and acceptance of different views.

In the context of family, shüra underlines the participation of all members of the family which instils in the family members a sense of belonging. This would indirectly create a spirit of cooperation which would motivate commitment. TTa 'ah (obedience) is considered one of the elements that is important and is considered not just a moral but also a legal responsibility of the Muslim wife. However, the concept of $t \bar{a}$ ' $a h$ should be differentiated from 'blind obedience'. ${ }^{19}$

Through the shiurā-process, relationships between members of the family can be further enhanced. The man as head of the household has a contract with his 
family through the trust given to him by his family members to fulfil that trust. This responsibility is heavy and would necessitate cooperation from his family members through shürā. The community as a whole also becomes responsible for the accomplishment of the trust. However, no meaningful, extensive and long lasting cooperation is possible without any effective governance. All these traits can be effectively transmitted through 'leadership by example' in the family setting.

Figure 1 shows this relationship and its connectivity to qur'ānic guidance. For effective family governance, three component parts of the society play major roles. The players are the individual, family, and the state. Basically, family governance starts with educating the individuals (informally and formally). An individual is the basis and the point around which the family's virtues revolve. An individual is a representative (khalïfah) of God on earth and this ultimately puts God at the centre. A khaliffah has basic responsibilities as commanded by God: to perfect himself, the society and the physical world. As expected, an individual as khaliffah must comply with the instructions of God - to be just, obey Allah's commandments, abstain from the prohibitions. All these can only be done if one is knowledgeable. When an individual complies with these instructions (injunctions of Allah), it is certain that he will perform his responsibilities and accord the deserved rights to his family members. Then man would be said to have fulfilled God's amānah and as such perfect himself.

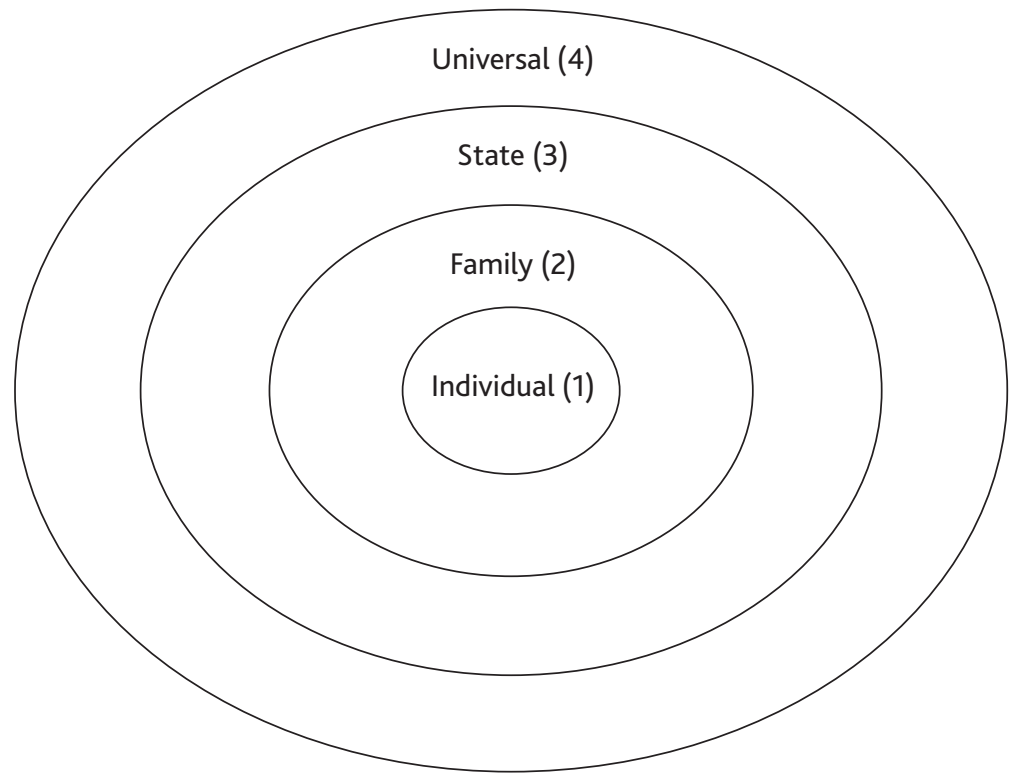

Figure 1 Qur'ānic Guidance on the Family 
The baton moves from there to the family. The family is a social institution responsible for the shaping of the larger society. An individual who is an integral part of the family must lead by example for the members of the family to emulate. As amānah must be fulfilled by the individual so also must amānah be fulfilled by the family. This is better done by inculcating the discipline and culture of good virtues on the members of the family, particularly the offspring. The children must be taught their role as the khaliffah of Allah, all members of the family must be just to one another and a family must be just to its neighbours - other families. In other words, each member of the family should see himself/herself as khaliffah to the entire family. In turn, each family must see itself as khaliffah to other families.

The natural consequence of this is that a just and prosperous society (state) will be built. To uphold this virtue, the state must be well constituted by consultation $(\operatorname{sh} \bar{u} \bar{a})$ among members of the just families or among the members of the community. As the state expands, so does the consultation involve private, public, men, women, and non-Muslims living under Islamic jurisdiction in order to fulfil the trust as members of the society. This does not only reiterate the concept of democracy but also the principle of fairness and justice in the administration of the state-amānah.

The sincere administration of amānah would deliver a number of basic elements of good family governance, such as the participation of the people in the public affairs, general consensus on major issues, quick response to the societal needs, rule of law, transparency, accountability, equity and efficiency. Hence, the society will be free of all vices. This, the Prophet founded in Medina in the seventh century.

A fair and equitable state will be just and equitable to its neighbouring states. And where all states discharge their responsibilities and fulfil their amānah, the whole universe will be better for it. Hence, an individual who sees himself as khaliffah, who carries out his duties and responsibilities, and who is just through self-discipline and good governance perfects himself. This is planted in his family and further transplanted into the state and by so doing perfects the society.

The perfection of the society leads to perfection of the physical world - the universe. That is the totality of man's responsibility in life. Thus, God who is at the centre bestows man with some of His qualities. The qualities are expected to be exhibited by an individual to himself, then to his family and family to the state and ultimately to the entire universe.

In this context, the role of the state is important in ensuring that family is stable and secured. Several mechanisms could be used to achieve this purpose, which includes the legal mechanism guided by relevant policies relating to the family. However, the extent or justification of state intervention in family matters must not go beyond the individual's rights. 


\section{Focus Group: Educators}

There are many reasons why educators must become involved in the detection, treatment, and prevention of crimes amongst their pupils. In addition to professional and moral responsibility, school personnel have a unique opportunity to advocate for children in a way that no other adults except parents can. If the parent is also involved in crime, this need for advocacy on the part of the school becomes even more imperative.

Educators, as murabbūn though vital to the whole intervention picture, must be supported by other community members and agencies. As leaders in communities, educators are in an ideal position to initiate this type of teamwork. As educators, the primary goal is to enhance the learning of children and to remove barriers that make learning difficult. Educators should be trained to recognise and intervene when children are not able to fully benefit from their educational opportunities. This training makes them uniquely qualified to detect cues that may indicate that children are being maltreated. Schools are the only places in which children are seen daily. Therefore, educators have a chance to see changes in their appearance and behaviour.

At the heart of the question of the involvement of educators in any social problems may well be the ethical basis of the profession itself. Some of the strongest reasons for involvement come from professional responsibilities, basic principles of justice, and personal commitment of educators to the wellbeing of the children and families they serve. Educators have a keen sense of professional responsibility to the children in their care. They are concerned about these children, about their mental health, safety, and happiness. Educators are aware that they themselves are models and examples for the children they teach, and that they are the only readily available source of support, concern, and caring for many children. Educators want to do what is best for the children in their care because their professional standards require it. Educators are urged to teach coping strategies, how to read social cues and how to interpret social behaviour amongst their pupils. For example, kindergarten and primary school teachers could be engaged in identifying children coming from severely dysfunctional families, because the type of aggression and hostility demonstrated by a future criminal is often foreshadowed in unusual aggressiveness as early as age five or six. Enlisting the help of professionals to nip the problem in the bud is easier than when these children have turned into monsters.

\section{Focus Group: Vulnerable Families}

Traditionally, most interventions have relied on specialist or professional input to children, parents or families. Increasingly strategies are being used to strengthen the help and advice available to families informally, whether from their kin, neighbour 
and friendship networks or through linking families with a volunteer. Such help may be less expert than professional services, but it is often more acceptable, more flexible and more available. As widely known, Islam stresses neighbours' rights and responsibilities which form the basis of a community.

Gilligan and others have argued that children's social and community networks are of vital importance when considering the development of effective interventions. This is no doubt true, but for very young children it is somewhat difficult to do. ${ }^{20}$

Parents should be taught to be kind to their children and provide them with love and warmth. Researchers have found that the most effective way to buffer our children from crime is for mothers to bond with their children through love. The mother's strong affectionate attachment to her child is the child's best buffer against a life of crime.

Fathers are equally important because his authority and involvement in raising his children will ensure that they will become good citizens. The dominant role of fathers in preventing delinquency is well-established and this phenomenon was highlighted in studies by Sheldon and Eleanor Glueck of Harvard University which sums up father's dominance as what many children often hear their mothers say; "Wait till your father gets home!"21

In this context it is largely the networks of parents that need to be considered, though these do then impact on young children's own social networks. Support networks can provide and educate parents with the buffers from stress, access to information and boost their confidence in ways that would allow them to parent more effectively.

It is therefore important for professionals involved with vulnerable families to be aware of the importance of these networks and provide interventions that will complement them. Gilligan identifies several ways that professionals can assist young people in keeping contact with existing social networks. ${ }^{22}$ Briefly they include:

- mapping the network by establishing who it incorporates;

- validating the network by pointing out to all involved the significance of the network;

- gathering relevant information from members of the network;

- negotiating and mediating between the focal member and other members of the network, especially if communications break down;

- negotiation and mediation between the focal member and other professionals;

- co-ordination of meetings and information sharing between focal member and other network members; and

- helping to reinforce the identity of the network through arranging celebrations and outings for special occasions. 


\section{A Social Network Model of Intervention for Dysfunctional Families}

A more common approach to expanding the informal resources available to families, especially in the United Kingdom, has been the development of volunteer befriending schemes. One such example is Home Start. This is a voluntary organisation in which trained volunteers offer regular support, friendship and practical help to young families under stress in their own homes, helping to prevent family crisis and breakdown. Home Start provides a range of practical help, advice and support. A wide range of referrals are accepted, but most common are depressed or isolated young mothers. The aim of Home Start is to build on the existing resources of families and the communities they live in. ${ }^{23}$

Research has shown that volunteers help families with quite similar needs and risks to those in touch with social services. Parents were significantly more satisfied with the help from their volunteers than were social workers' clients with their more formal 'help'. Part of the explanation appears to be the greater time that volunteers can spend with the family, though their independence from statutory agencies doubtless contributes too.

The New Parent Infant Network (NEWPIN) provides another example of a community support programme based on befriending, but also giving access to a wider range of services. The initial programme was based in London, although it has now expanded to other areas. It is specifically targeted at vulnerable mothers where there is a danger of family breakdown. More specifically it is aimed at mothers suffering depression, social isolation and poverty. ${ }^{24}$ The majority of referrals come from health and social work, although a few are self-referrals. Most of the work is done through therapy, training and social involvement with a peer group who provide added support. Initially mothers are matched with a befriender who is an established NEWPIN user. In addition there is also the opportunity to attend a drop-in centre with crèche, and participate in training such as a personal development programme.

It is therefore not disputed that personal and community networks can provide assistance to parents in ways that more formal support cannot. However, some appear to be inappropriate in view of low take-up or high drop-out rates.

\section{Focus Group: Religious Leaders}

Why religious leaders? First, the escalating number of violent crimes has been highlighted as an undesirable phenomenon of modern-day stressful living. It is one of the indicators that our traditional values are being eroded. The government's aim to prosper without sacrificing the values we grew up with and to share them with our children is noble and should not be overlooked.

Religious leaders' moral authority and their vast constituencies make them uniquely powerful allies for a peaceful society. Engaging religious leaders who 
are used to the "inside out" approach can be strengthened to assist the current mechanism. Religious groups should unite around this common cause. We should engage religious leaders because empirical evidence has shown that neighbourhoods with a high degree of religious practice are generally not high-crime neighbourhoods. Religious leaders' roles in instilling good values to individuals who in turn will be leaders of their own families are in urgent need. ${ }^{25}$ It is relevant in the context of serious commitment made by religious leaders in ensuring propagation of values in all spheres of life. Religious communities are uniquely positioned to apply their areas of strength to confront and prevent crime from escalating. These areas include consciousness raising, the empowerment of children, and inter- and intra-faith actions. For example, religious communities, working with adults, can promote and strengthen non-violent approaches to parenting.

\section{Conclusions and Recommendations}

There is a dire need now to strengthen family values, as the present progress in the Malaysian context has created influences which threaten the foundations within a family:

- Crime is a 'cancer' eating into our society. Unless and until we deal with the root problem, i.e. the primary cause of it, the numbers will keep escalating.

- Actions taken must not attack these crimes through secondary or tertiary level intervention.

- It is already accepted that to create an angelic society is impossible. However, actions should be taken to lessen crime or at least to move toward damage control.

- It has been widely accepted that curbing crime requires a combined effort. Concerted effort by all parties, from neighbours to government agencies, in promoting a multi-agency approach in addressing the problem has been well placed. However, religious leaders have been left out. To be part of the team, multi-agency training for religious leaders should be organised first to ensure things move fast. Manpower at various levels of this group should also be increased.

- Within the religious communities themselves, a specific long-term solution targeted by these religious leaders would be to build up the people's inner strength by inculcating religious and moral values. One of the most effective ways would be through life-long learning.

- Couples wanting to marry should have pre-marriage counselling and periodic marriage counselling conducted by religious leaders in the course of their married life. This should be made available within the community. Religious 
groups have a part to play in organising workshops and training sessions on topics related to parenting, and to be held within the community. These sensitisation programmes should go beyond Friday sermons. They should play a more proactive role by using the new media because it covers a wide range of society and is easily accessible to the IT-savvy community. They should assist in initiating more creative television programmes in order to increase public awareness from their religious perspective. As leaders of influence, it is important to educate the people.

To conclude, the alternative to revitalising knowledge in contemporary societies to eradicate crime was spelled out by al-Ghazālī some 900 years ago. "Would not the sick die if he is given no food or drink or medicine", one of his wise men inquires. "Yes," says the assembled gathering, to which the wise man replies, "Similarly the heart will perish if it is cut off from wisdom and knowledge for three days." And al-Ghazālī adds, "whosoever lacks the love of knowledge has an ailing heart and his death is certain." It is the death of real knowledge that initiates the birth of crime.

\section{Notes}

1. “Teen Crime: Young Neglected by Families", letter by Tan Sri Lee Lam Thye, New Straits Times (Kuala Lumpur), 10 January 2010.

2. "Criminal Justice", available online at http://www.wadsworth.com/criminaljustice_d/ (accessed on 10 December 2010).

3. Cesare Lombroso, Crime: Its Causes and Remedies (Montclair NJ: Patterson Smith, 1968); “The Real Root Causes of Violent Crime: The Breakdown of Marriage, Family, and Community” (1995), available online at http://www.heritage.org/research/reports/1995/03/bg1026nbsp-the-real-rootcauses-of-violent-crime (accessed on 27 June 2011); Daniel J. Curran and Claire M. Renzetti, Theories of Crime (Boston MA: Allyn \& Bacon, 2001).

4. Robin Karr-Morse and Meredith S. Wiley, Ghosts from the Nursery: Tracing the Roots of Violence (New York: Atlantic Monthly Press, 1997); Bruce A. Arrigo (ed.), Social Justice, Criminal Justice (Belmont CA: Wadsworth, 1999); Mark S. Fleisher, Beggars and Thieves: Lives of Urban Street Criminals (Madison WI: University of Wisconsin Press, 1995). See also http//www.mdjunction. com/forums/dysfunctional-families (accessed on 27 June 2011).

5. R.P. Rohner and E.C. Rohner, "Antecedents and Consequences of Parental Rejection: A Theory of Emotional Abuse", Child Abuse and Neglect 4 (1980), 189-98; Karr-Morse and Wiley, Ghosts. For further reading on child abuse, physical abuse and neglect, psychological maltreatment, sexual abuse, single parents, and poverty etc. see http://family.jrank.org/pages/219/Child-Abuse. html\#ixzz1QR1LrUwN (accessed on 27 June 2011).

6. Zaleha Kamaruddin, "Dysfunctional Families and Crimes: Some Home Truths", available online at http://www. Ikim.gov.my/V5/index.php (accessed on 27 June 2011).

7. Kevin N. Wright and Karen E. Wright, Family Life, Delinquency, and Crime: A Policymaker's Guide (Darby PA: DIANE Publishing Co, 1994).

8. Sheldon and Eleanor Glueck, Unraveling Juvenile Delinquency (New York, The Commonwealth Fund, 1950); Claire M. Renzetti and Lynne Goodstein (eds), Women, Crime, and Criminal Justice (Los Angeles: Roxbury, 2001). 
9. Robert K. Merton, "Social Structure and Anomie: Revisions and Extensions", in: Ruth Anshen (ed.), The Family (New York: Harper Brothers, 1949).

10. Kitab al- 'Ilm of Al-Ghazzali's Ihya' 'Ulum al-Din, transl. Nabih Amin Faris (Lahore: Sh.Muhammad Ashraf, 1979), also available online at http://www.ghazali.org/works/bk1-sec1.htm (accessed on 10 December 2010).

11. Ziauddin Sardar (ed.), How We Know: Ilm and the Revival of Knowledge (London: Grey Seal Books, 1991).

12. Idem, "Reformist Ideas and the Muslim Intellectuals", in: Abdullah Omar Naseef (ed.), Today's Problems, Tomorrow's Solutions: Future Thoughts on the Structure of Muslim Society (London: Mansell, 1988).

13. Muḥammad al-Ṭāhir Ibn 'Āshūr, Maqāṣid al-sharī'ah al-islāmiyyah (Amman: Dār al-Nafā'is, 1999).

14. Qur'ān 30:31.

15. Fazlur Rahman, “The Quranic Concept of God, the Universe and Man”, in: Bryan S. Turner (ed.), Islam: Critical Concepts in Sociology (London and New York: Routledge, 2003), vol. 1.

16. Ibrahim M. Zein et al., "Qur'anic Guidance on Good Governance", in: Abdullah al-Ahsan and Stephen B. Young (eds), Guidance for Good Governance: Explorations in Qur'anic, Scientific and Cross-Cultural Approaches (Kuala Lumpur: International Islamic University Press, 2008).

17. For further reading on rights and responsibilities in the family, see also Hammudah 'Abd Al 'Ati, The Family Structure in Islam (Petaling Jaya [Malaysia]: The Other Press, 2008).

18. Abdullah Yusuf Ali (transl.), The Meaning of the Holy Qur'an (Beltsville MD: Amana Corporation, 1994).

19. See note 16 .

20. R. Gilligan, "Family Support: Issues and Prospects", in: J. Canavan, P. Dolan, and J. Pinkerton (eds), Family Support: Direction from Diversity (London: Jessica Kingsley Publishers, 2000); John Bowlby, A Secure Base: Parent-Child Attachment and Healthy Human Development (New York: Basic Books, 1988).

21. See note 8 .

22. See note 20 .

23. J.J. Asscher, J.M. Hermanns, and M. Deković, "Effectiveness of the Home-Start Parenting Support Program: Behavioral Outcomes for Parents and Children", Infant Mental Health Journal 29 (2008), 95-113.

24. http//www.scotland.gov.uk/publications/2003/01/15814/13977 (accessed on 10 December 2010).

25. See note 6 . 